Bangladesh J. Plant Taxon. 19(2): 101-108, 2012 (December)

(C) 2012 Bangladesh Association of Plant Taxonomists

\title{
FOLIAR ANATOMY OF CYNOGLOSSUM L. (BORAGINACEAE) FROM NORTH ANATOLIA, TURKEY
}

\author{
ÖZnur ERgen AKÇIN ${ }^{1}$, Kamil ÇoŞKunÇELEBI ${ }^{2}$ anD GÜlCAN ŞENEL ${ }^{3}$ \\ Department of Biology, Sciences and Arts Faculty, Ordu University, Turkey
}

Keywords: Foliar Anatomy; Boraginaceae; Cynoglossum; Turkey.

\begin{abstract}
Bracts, basal and cauline leaves of North Anatolian representatives of Cynoglossum, viz., C. creticum Miller, C. officinale L., C. montanum L. and C. glochidiatum Wall. were investigated anatomically. Foliar thickness, trichome length and types, stomata types, stomata index, the presence of collenchyma and sclerenchyma were found to be important for delimitation of Cynoglossum species. All examined species have isobilateral leaf. Stomata were anisocytic and anomocytic. All the studied species had trichomes. Simple long and short trichomes were seen in leaves of C. creticum. Long and short trichomes with cystoliths at the base were seen in all leaves of C. montanum. Unicellular and multicellular unbranched trichomes and glandular trichomes were found in leaves of $C$. officinale. Short and adpressed trichomes were seen in leaves of $C$. glochidiatum.
\end{abstract}

\section{Introduction}

Cynoglossum L. (Boraginaceae) is represented by eight species in Turkey (Riedl, 1978). It is taxonomically difficult genus because of the fairly uniformity in external morphology. They generally grow along roadsides, sand dunes or open woodlands (Riedl, 1978; Sutory, 2005). Some species of the Cynoglossum are used as remedies in Anatolian folk medicines and as ornamental plants in gardens and parks (Baytop, 1999).

Over the last couple of decades, several studies were carried out on Cynoglossum based on ecology, seed germination and chemical structure (Boorman and Fuller, 1984; Fisher et al., 1989; Stabell et al., 1998), however, very little is known about anatomical properties of this genus. Metcalfe and Chalk (1979) and Watson and Dallwitz (1991) highlighted characteristic properties of petiole and leaf anatomy of Boraginaceae. Dasti et al. (2003) stressed that the epidermal characteristics, such as shape and size of the epidermal cells, types of trichomes and of stomata provide extensive taxonomic data in Boraginaceae. Riedl (1978) states that most of the Turkish Cynoglossum representatives are poorly defined and some additional characters are needed for proper identification of Cynoglossum. Akçin and Bilgener (2000) carried out a chemotaxonomic study on some Turkish Cynoglossum representatives in order to explore their taxonomic value. Dasti et al. (2003) examined the epidermal morphology of C. glochidiatum Wall. and C. tomentosa (Wall.) Kazmi. Akçin (2008) studied the micromorphology of nutlet and seeds of some Cynoglossum species. However, no detailed anatomical studies were carried out so far on Turkish Cynoglossum species which are often difficult to distinguish from one another morphologically. The present study aims to examine the foliar anatomical properties of four North Anatolian species of Cynoglossum, namely C. creticum Miller, C. officinale L., C. montanum L. and C. glochidiatum Wall. and to evaluate their discriminative potential in taxonomy.

\footnotetext{
${ }^{1}$ Corresponding author. Email: oakcin@gmail.com

${ }^{2}$ Department of Biology, Karadeniz Technical University, Turkey

${ }^{3}$ Department of Biology, Ondokuz Mayıs University, Turkey
} 


\section{Materials and Methods}

All the four Cynoglossum species were collected from North Anatolia in Turkey during 20012009. Voucher specimens were kept at the Ondokuz Mayıs University Herbarium.

Samples for anatomical studies were fixed in $70 \%$ alcohol. Cross and surface sections were prepared from the stored leaf materials. Cross and surface sections of leaves were excised by hand and they were covered with glycerin-gelatin (Vardar, 1987). The photographs were taken with Nikon FDX-35 microscope. All measurements were calculated with an ocular-micrometer under light microscope. Stomata index was calculated according to Meidner and Mansfield (1968).

Table 1. The anatomical properties in cross-section of basal leaves of Cynoglossum species.

\begin{tabular}{lcccc}
\hline \multicolumn{1}{c}{ Characters } & C. creticum & C. montanum & C. officinale & C. glochidiatum \\
& Min.-Max. & Min.-Max. & Min.-Max. & Min.-Max. \\
\hline Leaf thickness $(\mu \mathrm{m})$ & $250-460$ & $190-220$ & $180-230$ & $340-400$ \\
Cuticle thickness $(\mu \mathrm{m})$ & $2.5-5.0$ & $5.0-7.5$ & $5.0-7.5$ & $2.5-5.0$ \\
Trichome length $(\mu \mathrm{m})$ & $100-600$ & $120-1500$ & $120-600$ & $100-270$ \\
Palisade parenchyma (adaxial & $2 / 1-2$ layered & $2 / 1$ layered & $1 / 1$ layered & $2 / 1$ layered \\
/abaxial surface) & $4-6$ layered & $3-4$ layered & $3-4$ layered & $3-4$ layered \\
Spongy parenchyma & parenchymatic & parenchymatic & parenchymatic & parenchymatic \\
Bundle sheath & $25-70$ & $35-40$ & $35.0-37.5$ & $30-50$ \\
Epidermis cell length $(\mu \mathrm{m})$ & $12.5-37.5$ & $22.5-27.5$ & $17.5-30.0$ & $20-40$ \\
Epidermis cell width $(\mu \mathrm{m})$ & collateral & collateral & collateral & collateral \\
Type of vascular bundle & & & & \\
\hline
\end{tabular}

\section{Results}

\section{Cynoglossum creticum}

Epidermis consists of a single layer both in abaxial and adaxial surface of basal leaf (Table 1, Figs 1-3). Leaf is isolateral. Vascular bundles are surrounded by bundle sheath with big starch grains. Collenchymatic cells are located under the adaxial epidermis in the midrib. Some parenchymatic cells contain crystal near the median vein. On the abaxial side of the leaves trichome frequency is higher than adaxial side. The stomata are present on both adaxial and abaxial epidermis. Stomatal types are of anomocytic and anisocytic, but mainly anomocytic. The stomata index is 20.98 for adaxial surface and 30.66 for abaxial surface. Cauline leaf is isolateral. Mesophyll consists of 2 layers palisade cells in adaxial surface, 1-2 layers in abaxial surface and 2-3 layers spongy parenchyma cells. Vascular bundles are surrounded by a parenchymatic bundle sheath and collateral type. Both anomocytic and anisocytic stomata were found. The stomata index is 19.79 for adaxial surface and 23.59 for abaxial surface. There are trichomes on both sides of the leaves and trichomes frequency is almost same (Table 2, Figs 4-8).

In bract, palisade parenchyma cells are 2 layered on adaxial surface and 1-2 layered on abaxial surface. Vascular bundles more frequent than in cauline leaves. The number of epidermal cells on adaxial surface is 290- 352 and these values are nearly same on abaxial surface (Table 3, Fig. 9). The stomata index is 23.02 for adaxial surface and 28.50 for abaxial surface. 

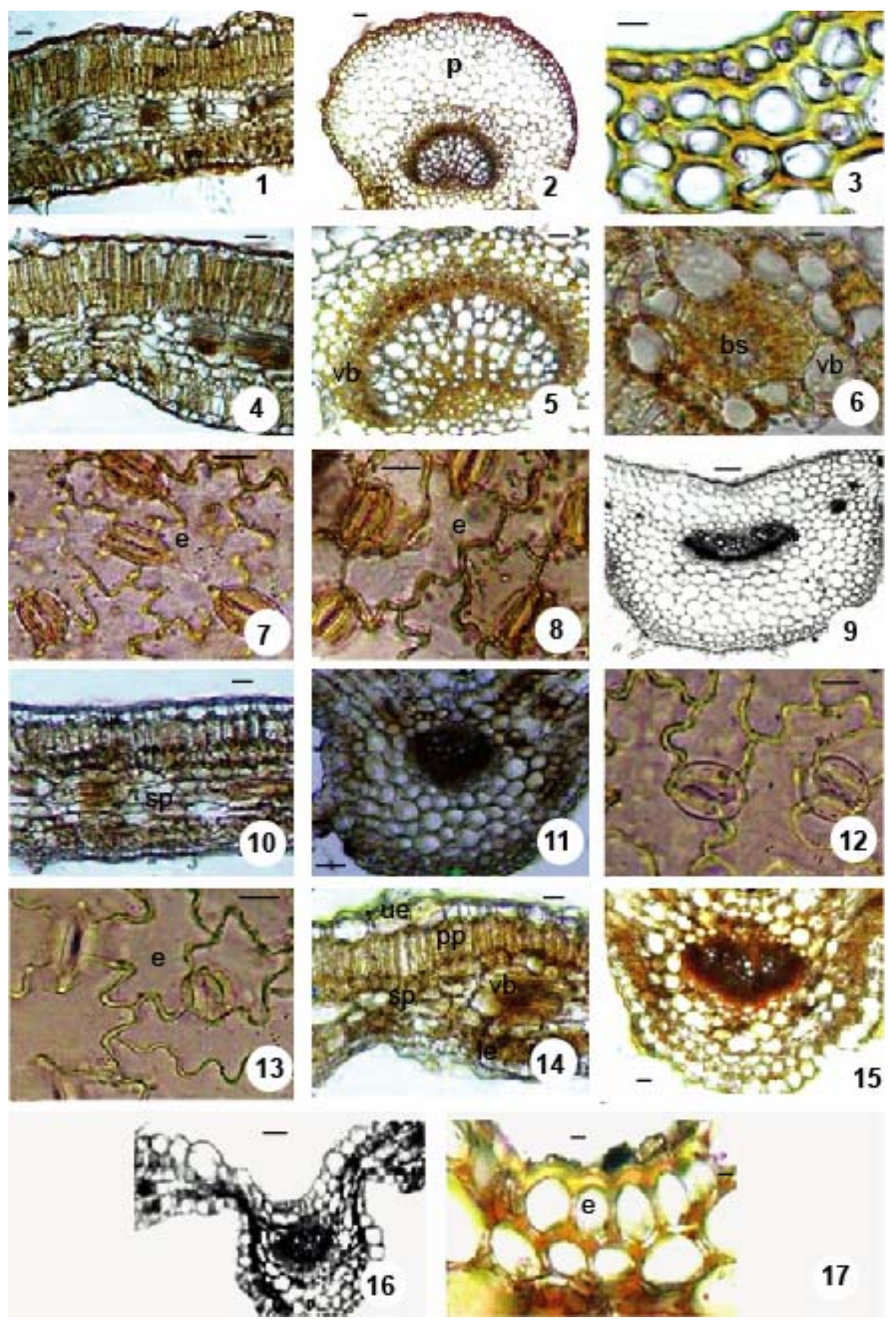

Figs 1-17. Transverse and surface section of Cynoglossum creticum and C. montanum leaves. 1-9. C. creticum. 1-3. basal leaf. 4-8. cauline leaf. 9. bract; 10-17. C. montanum. 10-13. basal leaf. 14-15. cauline leaf. 16-17. bract. e- epidermis; ue- upper epidermis; le- lower epidermis; cl- collenchyma; p- parenchyma; pp- palisade parenchyma; sp- spongy parenchyma; vb- vascular bundle; bs- bundle sheath; st- stomata; h- trichomes. Bar: $15 \mu \mathrm{m}$ (Figs 7-8); $20 \mu \mathrm{m}$ (Figs 12-13, 17); $40 \mu \mathrm{m}$ (Figs 10, 14-16); $50 \mu \mathrm{m}$ (Fig. 4); $70 \mu \mathrm{m}$ (Figs 1,3,5-6); $100 \mu \mathrm{m}$ (Figs 2, 9, 11). 


\section{Cynoglossum montanum}

In basal leaf epidermis consists of irregular shaped cells. Leaf is isolateral. Mesophyll composed of 2 layered palisade parenchyma cells in adaxial surface, 1 layer in abaxial surface and 3-4 layers spongy parenchyma cells. The stomata are more frequent on the abaxial side when compared to the on adaxial side. Stomatal types are anomocytic and anisocytic (Table 1, Figs 1013). The stomata index is 20.58 for adaxial surfaces and 23.25 for abaxial surfaces.

Table 2. The anatomical properties in cross-section of cauline leaves of Cynoglossum species.

\begin{tabular}{lcccc}
\hline Characters & $\begin{array}{c}\text { C. creticum } \\
\text { Min.-Max. }\end{array}$ & $\begin{array}{c}\text { C. montanum } \\
\text { Min.-Max. }\end{array}$ & $\begin{array}{c}\text { C. officinale } \\
\text { Min.-Max. }\end{array}$ & $\begin{array}{c}\text { C. glochidiatum } \\
\text { Min.-Max. }\end{array}$ \\
\hline Leaf thickness $(\mu \mathrm{m})$ & $200-300$ & $130-180$ & $200-250$ & $170-200$ \\
Cuticle thickness $(\mu \mathrm{m})$ & $5.0-7.5$ & $5.0-7.5$ & $2.5-5.0$ & $5.0-7.5$ \\
Trichome length $(\mu \mathrm{m})$ & $80-440$ & $180-500$ & $100-300$ & $180-200$ \\
Palisade parenchyma (adaxial/ & $2 / 1-2$ layered & $2 / 1$ layered & $1 / 1$ layered & $2 / 1$ layered \\
abaxial surface) & $2-3$ layered & $2-3$ layered & $3-4$ layered & $3-4$ layered \\
Spongy parenchyma & parenchymatic & parenchymatic & parenchymatic & parenchymatic \\
Bundle sheath & $30-50$ & $30-50$ & $15.0-37.5$ & $20.0-37.5$ \\
Epidermis cell length $(\mu \mathrm{m})$ & $20-30$ & $20.0-22.5$ & $12.5-20.0$ & $22.5-27.5$ \\
Epidermis cell width $(\mu \mathrm{m})$ & collateral & collateral & collateral & collateral \\
Type of vascular bundle & & & &
\end{tabular}

Table 3. The anatomical properties in cross-section of bracts of Cynoglossum species.

\begin{tabular}{lcccc}
\hline Characters & $\begin{array}{c}\text { C. creticum } \\
\text { Min.-Max. }\end{array}$ & $\begin{array}{c}\text { C. montanum } \\
\text { Min.-Max. }\end{array}$ & $\begin{array}{c}\text { C. officinale } \\
\text { Min.-Max. }\end{array}$ & $\begin{array}{c}\text { C. glochidiatum } \\
\text { Min.-Max. }\end{array}$ \\
\hline Leaf thickness $(\mu \mathrm{m})$ & $190-270$ & $200-220$ & $200-300$ & $272-300$ \\
Cuticle thickness $(\mu \mathrm{m})$ & $5.0-7.5$ & $2.5-5.0$ & $2.5-5.0$ & $2.5-5.0$ \\
Trichome length $(\mu \mathrm{m})$ & $100-320$ & $40-100$ & $40-250$ & $150-300$ \\
Palisade parenchyma & $2 / 1-2$ layered & $2 / 1$ layered & $1 / 1$ layered & $2 / 1$ layered \\
(adaxial /abaxial surface) & 3 layered & $3-4$ layered & $3-4$ layered & $3-4$ layered \\
Spongy parenchyma & parenchymatic & parenchymatic & parenchymatic & parenchymatic \\
Bundle sheath & $15-30$ & $40.0-42.5$ & $25.0-32.5$ & $25-30$ \\
Epidermis cell length $(\mu \mathrm{m})$ & $10-20$ & $20-40$ & $20.0-12.5$ & $12.5-22.5$ \\
Epidermis cell width $(\mu \mathrm{m})$ & collateral & collateral & collateral & collateral \\
Type of vascular bundle & & & & \\
\hline
\end{tabular}

Cauline leaf is isolateral. Bundle sheath is not distinguishable. There are sclerenchymatic cells in the midrib. Collenchymatic cells are located under the adaxial epidermis. Stomatal types are of anomocytic and anisocytic (Table 2, Figs 14-15). The stomata index is 20 for adaxial surface and 17.79 for abaxial surface. In bract, mesophyll composed of 2 layered palisade parenchyma cells in adaxial surface, 1 layered in abaxial surface and 3-4 layered spongy parenchyma cells. Distinguishable angular collenchyma is present in the median region of leaf (Table 3, Figs 16-17). The stomata index is 20.45 for adaxial surface and 23.30 for abaxial surface. 

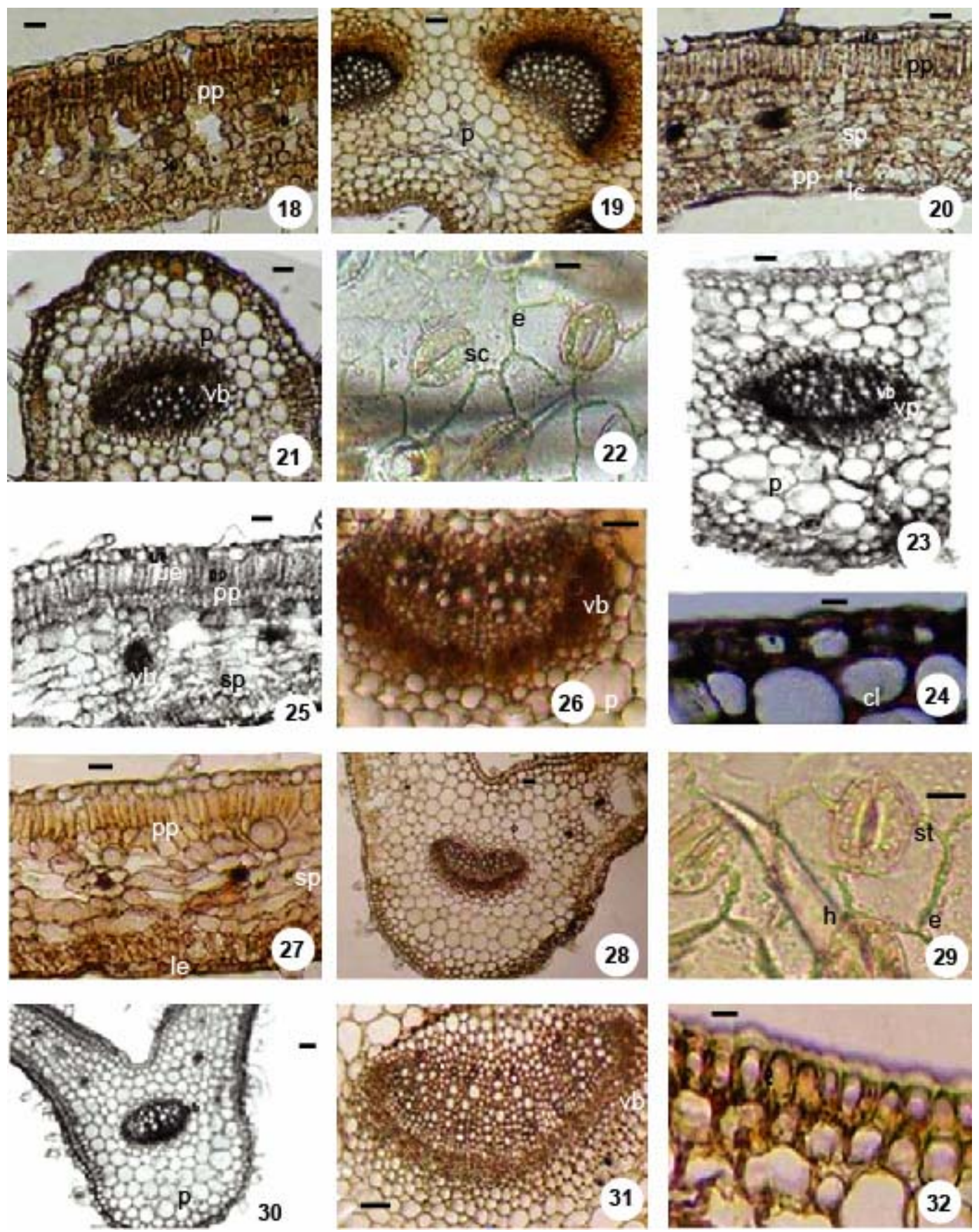

Figs 18-32. Transverse and surface section of Cynoglossum officinale and C. glochidiatum leaves. 18-24. C. officinale. 18-19. basal leaf. 20-22. cauline leaf. 23-24. bract; 25-32. C. glochidiatum. 25-26. basal leaf. 27-29. cauline leaf. 30-32. bract. Bar: $15 \mu \mathrm{m}$ (Fig. 29); $20 \mu$ (Fig. 22); $40 \mu \mathrm{m}$ (Figs 18, 20, 24); $70 \mu \mathrm{m}$ (Figs 25, 27, 28, 30, 32); $80 \mu \mathrm{m}$ (Figs 19, 21, 23); $100 \mu \mathrm{m}$ (Figs 26, 31). 


\section{Cynoglossum officinale}

Basal leaf is isolateral. The stomata index on the adaxial side is 20.98 , on the abaxial side values is 30.68 (Table 1, Figs 18-19). Cauline leaf is isolateral. Palisade parenchyma cells are 1 layered in both surface. Spongy parenchyma cells are 3-4 layered. Stomata type is anomocytic and anisocytic. The stomata index is 15.78 for adaxial surface and 27.27 for abaxial surface (Table 2 Figs 20-22). In bract, palisade parenchyma cells are 1 layered in both adaxial and abaxial surfaces. Spongy parenchyma cells are 3-4 layered. Both anomocytic and anisocytic types of stomata were found, but mainly anomocytic type was observed (Table 3, Figs 23-24). The stomata index is 16.21 for adaxial surface and 24.71 for abaxial surface.
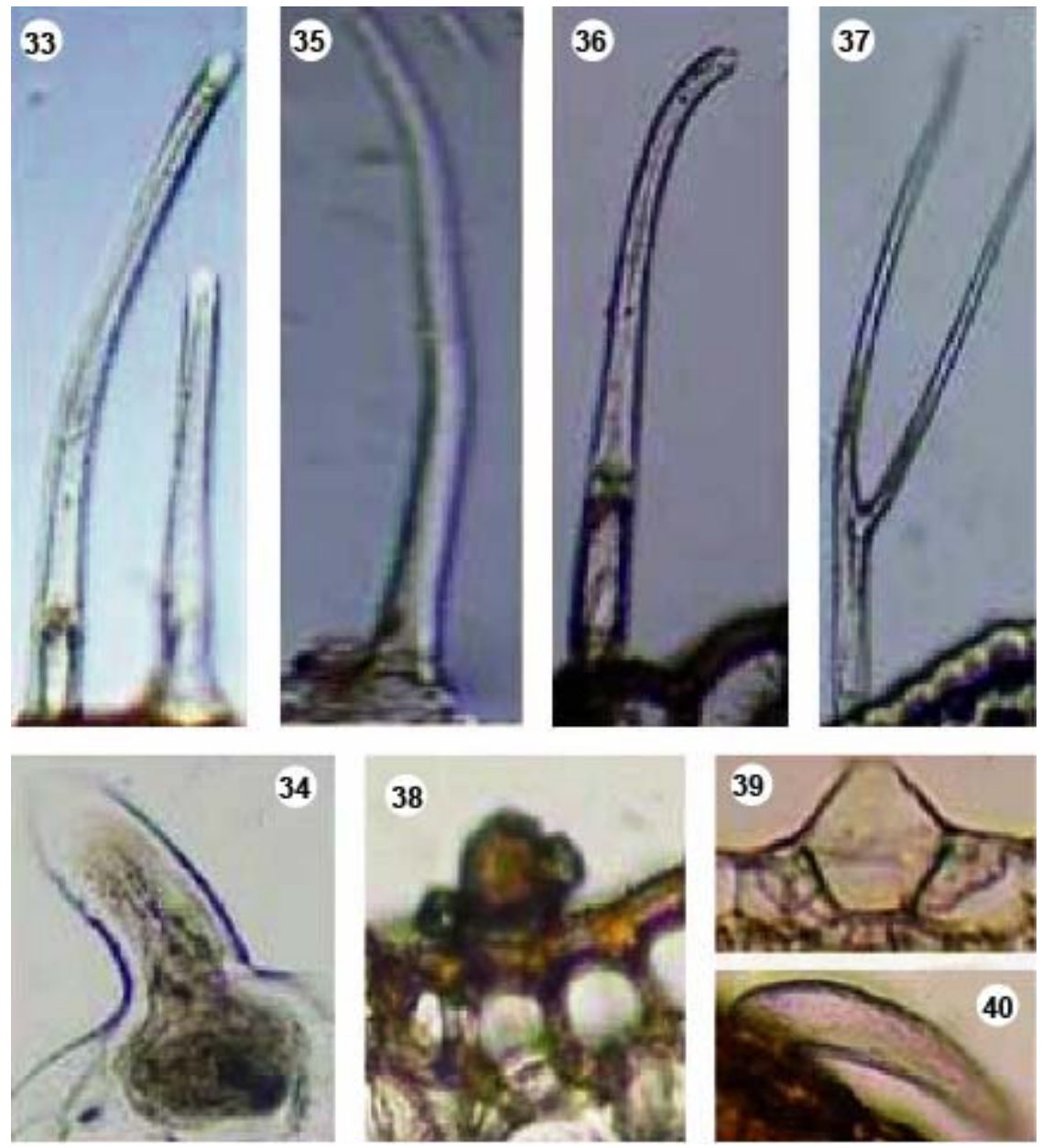

Figs 33-40. Trichomes of Cynoglossum species. Fig. 33. Simple trichomes of C.creticum. Figs 34-35 Short trichomes with cystolith at the base and long simple trichomes of C. montanum. Figs 36-38. Unbranced, branched trichomes and glandular trichomes of C. officinale. Figs 39-40. Simple trichomes of C. glochidiatum.

\section{Cynoglossum glochidiatum}

Epidermis is single layered on both adaxial and abaxial surfaces of basal leaf. Leaf is isolateral. Palisade parenchyma cells are 2 layered on adaxial surface and 1-layered on abaxial 
surface. Spongy parenchyma cells are 3-4 layered. C. glochidiatum have trichomes and stomata both adaxial and abaxial sides. Stomata length is $20-25 \mu \mathrm{m}$ and stomata width is $5-10 \mu \mathrm{m}$ (Table 1, Figs 25-26). There is a thick cuticle on cauline leaf. Epidermal cells are isodiametric and oval. Leaf is isolateral. Stomata type is anomocytic and anisocytic (Table 2, Figs 27-29). The stomata index is 29.41 for adaxial epidermis, 20.45 for abaxial epidermis. In bract epidermis consists of uniserate, rectangular cells. Palisade parenchyma cells are 2 layered on adaxial surface and 1 layered on abaxial surface. Spongy parenchyma cells are 3-4 layered. Collenchymatic cells are located under the epidermis in midrib region. The bundle sheath is parenchymatic (Table 3, Figs. 30-32). The stomata index is 22.04 for adaxial surfaces and 22.64 for abaxial surface.

All the studied species had trichomes. Simple long and short trichomes were seen in basal, cauline leaf and bract of the C. creticum (Fig. 33). Long and short trichomes with cystoliths at the base were seen on the both epidermises on basal and cauline leaves of C. montanum (Figs 34-35). Unicellular and multicellular unbranced trichomes and glandular trichomes were found in leaves of C. officinale. Also branched multicellular with nearly two equal arms trichomes were rarely presented in basal leaf of this species (Figs 36-38). Usually short and adpressed trichomes were seen in all leaves of C. glochidiatum (Figs 39-40).

\section{Discussion}

In the present study isobilateral (isolateral) types of leaf were observed in all examined species. Metcalfe and Chalk (1979) reported that there are centric or isobilateral mesophyll types in Boraginaceae. While the row number of palisade cells varies among species, it is very stable in the same species. Presence of collenchyma and sclerenchyma in leaves is an important feature (Mavi et al., 2011). Sclerenchymatic and collenchymatic cells were located in the midrib of $C$. montanum. The other species had collenchymatic cells. Metcalfe and Chalk (1979) reported that there are both anomocytic and anisocytic stomata in Boraginaceae, but Özörgücü et al. (1991) reported only anomocytic stomata in this family. Our findings support Metcalfe and Chalk (1979). It was also found that all species have stomata on both upper and lower surfaces. Dasti et al. (2003) reported that anomocyctic and helicocytic stomata were seen in leaves of C. glochidiatum and C. tomentosa. Stomata were anisocytic and anomocytic in Onosma angustissimum Hausskn. $\&$ Bornm. and O. cassium Boiss. (Boraginaceae) (Akçin and Binzet, 2010). The stomata numbers are more in abaxial surface than adaxial surface in the most of examined species. The stomata index differs for the adaxial and abaxial epidermis among four examined species. Stomata index is important as the number of stomata may be changed by the age of the leaf, but the stomata index remains constant for a species (Trease and Evans, 1982). Metcalfe and Chalk (1979) and Watson and Dallwitz (1991) reported that crystalloids, especially calcium oxalate crystals were present in the mesophyll of leaves of Boraginaceae family. Fisher et al. (1989) suggested that nuclear crystalloids were found in high percentage in Boraginaceae family and these inclusions could be valuable as a systematic character. In this study, it was found that cystoliths were present in hair base in all studied species.

The present study based on foliar anatomical characters supports the traditional taxonomic treatments of Cynoglossum. Leaves of Cynoglossum species contain diagnostic features such as foliar thickness, trichome length, stomata types, stomata index, the presence of collenchyma and sclerenchyma, and their arrangement around the vascular bundles.

\section{References}

Akçin, Ö.E. 2008. Seed coat and fruit surface micromorphology of some Cynoglossum L. (Boraginaceae) species. Bangladesh J. Bot. 37(2): 115-119. 
Akçin, Ö.E. and Bilgener, M. 2000. A chemotaxonomical study on the some Cynoglossum L. (Boraginaceae) species. Ondokuz May1s Universty The Science Journal 11(1):76-84.

Akçin, Ö.E. and Binzet, R. 2010. The micromorphological and anatomical properties of Onosma angustissimum Hausskn. \& Bornm. and O. cassium Boiss. (Boraginaceae). Bangladesh J. Plant Taxon 17(1): $1-8$.

Baytop, T. 1999. Treatment with plants in Turkey. Nobel Tip Book Co., İstanbul.

Boorman, L.A. and Fuller, R.M. 1984. The comparative ecology of two sand dune biennials: Lactuca virosa L. and Cynoglossum officinale L. New Phytologist 96: 609-629.

Dasti, A.A., Bokhari, T.Z., Malik, A.S. and Akhtar, R. 2003. Epidermal morphology in some members of family Boraginaceae in Baluchistan. Asian Jour. Plant Sci. 2(1): 42-47.

Fisher, D.D., Thorsch, J. and Esau, K. 1989. Inclusions in nuclei and plastids of Boraginaceae and their possible taxonomic significance. Canadian J. Bot. 67: 3608-3617.

Mavi, Ö., Doğan, M., Başer, B., Pehlivan, S., Cabi, E. and Akaydın, G. 2011. Anatomy and pollen morphology of Leymus racemosus (Lam.) Tzvelev subsp. sabulosus (Bieb.) Tzvelev and Leymus cappadoiıcus (Boiss. \& Bal.) Melderis. Bangladesh J. Plant Taxon 18(1): 27-38.

Meidner, H. and Mansfield, T.A. 1968. Physiology of Stomata. McGraw-Hill, London.

Metcalfe, C.R. and Chalk, L. 1979. Anatomy of Dicotyledons I. Oxford University Press, London.

Özörgücü, B., Gemici, Y. and Türkan, I. 1991. Comparative Plant Anatomy. Ege University, No:129. Izmir.

Riedl, H. 1978. Cynoglossum L. In: Davis, P.H. (ed.), Flora of Turkey and the East Aegean Islands. Vol. 6. Edinburgh University Press, Edinburgh.

Stabell, E., Upadhyaya, M.K. and Ellis, B.E. 1998. Role of seed coat in regulation of seed dormancy in hound's tongue (Cynoglossum officinale). Weed Science 46: 344-350.

Sutory, K. 2005. A new species of Cynoglossum (Boraginaceae-Cynoglasseae) from Eastern Turkey. Edinburg J. Bot. 61:119-126.

Trease, G.H. and Evans, W.C. 1982. Pharmacognazi, $11^{\text {th }}$ edition. Cassel and Collier, McMillan Publishers Ltd., London. 722 pp.

Vardar, Y. 1987. Preparation Techniques in Botany. Ege University Press, Izmir. pp. 1-66.

Watson, L. and Dallwitz, M.J. 1991. The Families of Angiosperm: Automated descriptions, with interactive identification and information retrieval. Austr. Syst. Bot. 4: 681-695.

(Manuscript received on 16 September 2011; revised on 5 May 2012) 